\title{
Óráð eftir opna hjartaaðgerð: kerfisbundin samantekt á algengi, áhættupáttum og afleiðingum
}

\author{
Steinunn Arna Porsteinsdóttir,2 hjúkrunarfræðingur, Herdís Sveinsdóttir²,2 hjúkrunarfræðingur, Jón Snædal1,3 læknir
}

\section{ÁGRIP}

Óráð er bráð og yfirleitt tímabundin truflun á meðvitund, athygli, hugsun, skynjun og tilfinningum. Orsakir pess eru ekki að fullu pekktar en truflanir á taugaboðefnum og bólguviðbrögð eru mögulegir orsakapættir. Óráð er algengt vandamál eftir opnar hjartaaðgerðir og afleiðingar geta verið alvarlegar. Prátt fyrir pað sýna rannsóknir að vandamálið er vangreint og fyrirbyggingu og meðferð er ábótavant.

Tilgangurinn með pessari yfirlitsgrein er að varpa ljósi á algengi, áhættupætti og afleiðingar óráðs í kjölfar opinna hjartaaðgerða.

Gerð var kerfisbundin fræðileg samantekt á rannsóknargreinum frá árunum 2005-2013 til að skoða algengi, útsetjandi og útleysandi áhættupætti og afleiðingar óráðs eftir opnar hjartaaðgerðir. Leitað var í gagnagrunnunum Web of Science, PubMed og Cinahl.
Tæpur priðjungur sjúklinga fær óráð eftir opna hjartaaðgerð. Útsetjandi áhættupættir eru meðal annars hár aldur, vitræn skerðing, gáttatif, punglyndi og saga um heilablóðfall. Útleysandi áhættupættir eru meðal annars tími á hjarta- og lungnavél og öndunarvél, lágt útfall hjarta eftir aðgerð, öndunarbilun, lungnabólga, sýkingar, pörf fyrir blóðgjöf og hjartsláttaróregla eftir aðgerð. Óráð leiðir til lengri sjúkrahúslegu, skertrar sjálfsbjargargetu og hærri dánartíðni. Hægt er að fyrirbyggja óráð með pví að sporna við pekktum áhættupáttum.

Óráð er algengur og alvarlegur fylgikvilli opinna hjartaaðgerða. Með aukinni pekkingu á áhættupáttum, auk reglubundinnar skimunar fyrir einkennum, mætti draga úr algengi og flýta fyrir greiningu og meðferð.
'Skurðlækningarsviði Landspítala, ${ }^{2 h j u ́ k r u n a r-~}$ fræðideild Háskóla Íslands, ${ }^{3}$ öldrunarlækningadeild Landspítala Landakoti.

Fjórar yfirlitstöflur með greininni (nr. II-V) eru á heimasídu Læknablaðsins.

Fyrirspurnir: Steinunn Arna Porsteinsdóttir steitors@landspitali.is

Greinin barst 8. janúar 2015, sampykkt til birtingar 22. apríl 2015.

Höfundar hafa útfyllt eyðublað um hagsmunatengsl.

\section{Inngangur}

Óráð (delirium) er geðrænt heilkenni sem á sér vefrænar orsakir. Pað er brátt ástand sem próast á skömmum tíma og gengur oftast yfir á nokkrum klukkustundum eða dögum, en getur verið langvinnara., ${ }^{1,2}$ Bráðarugl (acute confusion) er annað heiti yfir petta heilkenni. Orðið delirium er komið úr latínu og er upphafleg merking pess í raun „að fara úr plógfarinu“. ${ }^{3}$ Par sem einkenni óráðs eru meðal annars breyting á meðvitund, truflun á athygli, minni, tali, skynjun, hreyfingum og tilfinningum ${ }^{1}$ er pó ekki fjarri lagi að peir sem fá óráð „fari úr plógfarinu“ í peirri merkingu að fólk verður ólíkt sjálfu sér.

Óráð er algengur fylgikvilli sjúkrahúslegu. Rannsóknir meðal skurðsjúklinga sýna algengi á bilinu 11$61 \%, 5$ og eftir opna hjartaaðgerð er algengi pess á bilinu 3-52\%. ${ }^{6}$ Ólíkar algengistölur skýrast af breytilegum úrtökum hvað varðar aldur og aðra áhættupætti óráðs og greiningaraðferðum sem notaðar eru. Fjölmargar rannsóknir hafa sýnt fram á neikvæð áhrif óráðs á batahorfur einstaklinga en prátt fyrir pað er vandamálið bæði vangreint og vanmeðhöndlað á sjúkrahúsum. . $7,78^{7}$ Sumar rannsóknir sýna að óráð er vangreint hjá allt að tveimur af hverjum premur sem pað fá.,99 Ófullnægjandi mat á vitrænum páttum, skortur á reglubundinni skimun og slök skráning lækna og hjúkrunarfræðinga eru dæmi um hindrandi pætti í fyrirbyggingu og greiningu vandamálsins.,10 Í erlendum leiðbeiningum um forvarnir og meðferð við óráði er áhersla lögð á að greina pá sem eru í aukinni áhættu vegna undirliggj- andi áhæettupátta, greina snemmkomin einkenni og að pekkja áhættupætti sem ýta undir ástandið og forðast pá. ${ }^{5,1-13}$ Forvörn er árangursrík og sýnt hefur verið fram á að fækka megi tilfellum óráðs um priðjung og draga úr alvarleika peirra með réttum starfsháttum. ${ }^{14,15}$ Meðferð getur hins vegar verið vandasöm eftir að óráð hefur komið til. ${ }^{16}$

Fyrsta opna hjartaaðgerðin var framkvæmd hérlendis árið 1986 og eru framkvæmdar um 200 opnar hjartaaðgerðir árlega á fullorðnum einstaklingum. Meðalaldur sjúklingahópsins hefur farið hækkandi hérlendis, árið 1990 var meðalaldur peirra sem gengust undir opna hjartaaðgerð 60,5 ár en 65,4 ár árið 2013. ${ }^{17}$ Í ljósi pess að peim fjölgar sífellt sem ná háum aldri og auknar tækniframfarir bjóða upp á flóknari og umfangsmeiri aðgerðir má álykta að peim fjölgi verulega sem teljast í hættu á að fá óráð, en hár aldur og heilabilun, sem hefur sterka fylgni við hækkandi aldur, eru meðal helstu áhættupátta óráðs..$^{18,19}$

Tilgangur pessarar greinar er að varpa ljósi á algengi, áhættupætti og afleiðingar óráðs eftir opnar hjartaaðgerðir. Byrjað er á almennri umfjöllun um óráð og pví næst gerð grein fyrir niðurstöðum kerfisbundinnar rannsóknarsamantektar á óráði eftir opna hjartaaðgerð.

\section{Skilgreiningar og greiningarviðmið fyrir órád}

Í ICD-10 (International Statistical Classification of Diseases and Health Related Problems, $10^{\text {th }}$ revision, ICD-10) 
er óráð skilgreint sem „,vefrænt heilaheilkenni af ósértækum uppruna, sem einkennist af truflunum á meðvitund og athygli, skynjun, hugsun, minni, skynhreyfivirkni, tilfinningum og svefn- og vökumynstri. Ástandið varir mislengi og getur verið allt frá vægu til alvarlegs ástands ${ }^{\prime 2}{ }^{20}$ Amerísku geðlæknasamtökin (American Psychiatric Association, APA) skilgreina óráð sem „skammvinna, vefræna geðröskun sem lýsir sér sem truflun á meðvitund með minnkaðri getu til að halda einbeitingu eða veita athygli. Breytingar verða á vitrænni getu, svo sem skert minni, ruglingslegar hugsanir og truflanir á tali eða aðrar breytingar, sem ekki eru til komnar vegna heilabilunar. Einkennin próast á stuttum tíma og eru breytileg yfir sólarhringinn“.1 Greiningarviðmið óráðs samkvæmt DSM-IV eru:

1. Truflun á meðvitund og minnkuð árvekni eða athygli á umhverfið, með minnkaðri getu til að veita og viðhalda athygli.

2. Truflun á vitrænni getu, svo sem skert minni, óáttun, truflun á tali eða skyntúlkun. Pessar breytingar eru ekki tilkomnar vegna heilabilunar.

3. Truflunin verður á stuttum tíma, vanalega dögum eða klukkustundum og er breytileg yfir sólarhringinn.

4. Vísbendingar koma fram í heilsufarssögu sjúklings, líkamsskoðun eða rannsóknarniðurstöðum, sem sýna að truflunina má rekja til lífeðlisfræðilegra afleiðinga almenns sjúkdómsástands eða notkunar lyfja.

Nýlega kom út 5. útgáfa DSM par sem greiningarviðmiðum um óráð hefur verið lítillega breytt og er í henni lögð minni áhersla á breytingu á meðvitund. Hér verður pó stuðst við 4 . útgáfuna par sem hún er til grundvallar í peim rannsóknum sem hér voru teknar saman.

Tafla I. Samanburður einkenna óráðs og heilabilunar. ${ }^{25}$

\begin{tabular}{ll}
\hline Óráð & Heilabilun \\
\hline Einkenni byrja skyndilega & Hægur gangur sjúkdóms \\
\hline $\begin{array}{l}\text { Breytileg yfir sólarhringinn, oft } \\
\text { verri á kvöldin og að nóttu til }\end{array}$ & $\begin{array}{l}\text { Hæg versnun einkenna yfir langan } \\
\text { tíma }\end{array}$ \\
\hline Breytilegt meðvitundarástand & Meðvitund óbreytt \\
\hline Trufluð athygli & Athygli oft óbreytt \\
\hline $\begin{array}{l}\text { Hugsun óskipulögð, brengluð, } \\
\text { samhengislaus, órökrétt, of hæg eða } \\
\text { of hröð }\end{array}$ & $\begin{array}{l}\text { Rökhugsun lakari, hugsun fátækleg, } \\
\text { dómgreind slök, málstol algengt }\end{array}$ \\
\hline $\begin{array}{l}\text { Skynjun: brengluð, ímyndanir, } \\
\text { misskynjanir, ofskynjanir, } \\
\text { veruleikabrenglun }\end{array}$ & Skyntruflanir ekki eins algengar \\
\hline Nærminni og langtímaminni skert & Nærminni og langtímaminni skert \\
\hline $\begin{array}{l}\text { Áttun oftast skert, breytileg frá einum } \\
\text { tíma til annars }\end{array}$ & Áttun getur verið skert \\
\hline $\begin{array}{l}\text { Varir oft stutt, frá klst og upp í } \\
\text { mánuð, sjaldan lengur }\end{array}$ & Varir í mánuði/ár \\
\hline Breytt árvekni & Árvekni oft óbreytt \\
\hline \begin{tabular}{l} 
Framvinda ófyrirsjáanleg \\
\hline
\end{tabular} & Einkenni vaxa með tímanum \\
\hline
\end{tabular}

\section{Orsakir óráds}

Orsakir óráđs eru ekki að fullu pekktar en líklega er um samspil margra pátta að ræða. ${ }^{21-23}$ Sumar orsakir er auðvelt að skilja og má par nefna beina áverka á heilann, svo sem súrefnisskort, heilablóðfall, lyfjaáhrif og efnaskiptatruflanir. ${ }^{23}$ Aðrar orsakir er erfiðara að skilja til fulls, eins og væga sýkingu eða áverka utan heilans. Í peim tilvikum mætti tala um óeðlilega streitusvörun heilans. Мeð „streitu“ er átt við bólguviðbrögð og ýmis hormónaviðbrögð líkamans og með „óeðlilegu“ er átt við að svörunin er ýkt og kemur meðal annars fram sem óráð. ${ }^{23}$

Margar rannsóknir hafa sýnt að óráð orsakast hugsanlega af bólgusvörun sem verður meðal annars vegna streituviðbragða líkamans við skurðaðgerð. ${ }^{21,22}$ Áhrif bólgumiðla á heilann fela í sér breytingar á flutningi taugaboða og frumudauða. Bólgumiðlar, eins og interleukin-1 $\beta$, TNF- $\alpha$ og interleukin-6, hafa áhrif á miðtaugakerfið par sem peir geta borist yfir blóðheilapröskuldinn og stuðlað að bólgusvörun í heila. Miklir áverkar, alvarleg veikindi og skurðaðgerð geta aukið gegndræpi blóðheilapröskuldsins sem annars ver heilann fyrir slíku áreiti. ${ }^{21}$ Heili aldraðra virðist bregðast frekar við pessari bólgusvörun en heili yngra fólks. Petta gæti einnig skýrt hvers vegna aldraðir eru útsettari fyrir óráði. ${ }^{21}$ Óráð í kjölfar hjartaaðgerðar hefur í sumum rannsóknum verið skýrt með örsmáum blóðtöppum (microemboli) ${ }^{24}$ en aðrar rannsóknir hafa ekki sýnt pað með óyggjandi hætti. ${ }^{27}$

Truflun taugaboðefna, og pá helst acetýlkólíns, er talin vera meðal orsaka óráðs. ${ }^{26}$ Acetýlkólín minnkar með hækkandi aldri og pað skýrir að hluta hvers vegna aldraðir eru útsettari fyrir óráði en peir yngri. Súrefnisskortur og lágur blóðsykur leiða til minni framleiðslu á acetýlkólíni og hafa báðir pessir pættir verið nefndir sem áhættupættir fyrir óráð. ${ }^{21,22,26}$ Truflun á sambandi acetýlkólíns og annarra taugaboðefna, svo sem dópamíns og serótóníns, virðist einnig hafa hlutverki að gegna í óráði. ${ }^{21,22,23}$

\section{Áhættupættir óráoss eftir skurðaògerð}

Áhættupáttum má í raun skipta í tvo flokka, annars vegar útsetjandi áhættupætti (predisposing factors) og hins vegar útleysandi áhættupætti (precipitating factors) ${ }^{5,22}$ Útsetjandi áhættupættir eru peir pættir sem gera einstaklinginn viðkvæmari eða móttækilegri fyrir ýmsum vandamálum. Petta eru áhættupættir sem oft eru til staðar við innlögn á sjúkrahús. Sem dæmi um slíka áhættupætti óráðs má nefna háan aldur, vitræna skerðingu, alvarleg veikindi og sjón- og heyrnarskerðingu. 18,19,28,29 Útleysandi áhættupættir eru hvers kyns truflun eða skaðvaldar tilkomnir vegna heilsufarsástands, meðferðar eða umhverfis, sem hrinda frekar af stað vandamálinu. Breytingar verða á líkamsástandi og umhverfi einstaklingsins við skurðaðgerðir og geta ýmsir útleysandi áhættupættir, svo sem verkir, truflanir á vökva- og saltbúskap, fasta og gjörgæsludvöl, fylgt í kjölfarið. ${ }^{1,30}$ Bráð skurðaðgerð getur haft aukna hættu á óráði í för með sér umfram valaðgerð ${ }^{19}$ Peir einstaklingar sem eru útsettari fyrir óráði vegna hás aldurs, heilabilunar eða annarra undirliggjandi áhættupátta purfa mun minna áreiti til að fá óráð en peir sem ekki hafa undirliggjandi áhættupætti. ${ }^{22,27,28}$ 


\section{Einkenni og greining óráos}

Óráð hefur ólíkar birtingarmyndir og mörg einkenna pess eru sameiginleg með öðrum klínískum vandamálum. Einkennum óráðs er gjarnan skipt í ofvirknieinkenni og vanvirknieinkenni. Um helmingur peirra sem fær óráð sýnir einkenni hvors tveggja, en pegar eingöngu koma fram vanvirknieinkenni er gjarnan talað um pögult óráð. Eitt helsta einkenni óráðs er truflun á meðvitundarástandi. Skyndileg truflun á vitrænni getu, svo sem athyglisbrestur, minnisskerðing og óáttun eru jafnframt oft fyrstu einkennin í vægu óráði. ${ }^{1}$ Skynáreiti, svo sem hljóð-, lyktar-, bragð-, snerti- eða sjónáreiti ,getur einstaklingur í óráði skynjað á allt annan hátt en vant er. ${ }^{1}$ Oft eru til staðar töluverðar sveiflur á skapi og tilfinningum, svo sem kvíði, ótti, depurð, pirringur, reiði, mikil vellíðan eða tilfinningadeyfð. ${ }^{1}$ Рað getur reynst erfitt að greina óráð vegna pess hve breytileg einkennin eru yfir sólarhringinn. Einnig getur reynst erfitt að greina á milli hvort einkennin séu vegna óráðs eða undirliggjandi heilabilunar (tafla I), par sem hvort tveggja felur í sér víðtæka truflun á vitrænni getu. Truflun á meðvitund og athygli, hröð próun einkenna og sveiflukenndar breytingar á ástandi yfir sólarhringinn eru helstu atriðin sem nota má til aðgreiningar. ${ }^{1}$

Reglubundin notkun staðlaðra mælitækja eða skimunarlista getur greitt fyrir nákvæmri greiningu á óráði. ${ }^{9}$ Einkenni sem lítið ber á, eins og pau sem koma fram í pöglu óráði, fara oft fram hjá heilbrigðisstarfsfólki ef ekki er sérstaklega leitað eftir peim og í peim tilfellum er gagnlegt að geta stuðst við matstæki til að meta einkennin. ${ }^{7,9}$ Eitt af peim matstækjum sem er hvað mest notað er CAM (Confusion assessment method). Раð er gjarnan notað í rannsóknum á algengi óráđs og í inngripsrannsóknum en einnig í klínískri vinnu. Í klínískum leiðbeiningum er oft mælt með notkun pess til greiningar á óráði. ${ }^{13}$ DOS-skimunarlistinn (Delirium Observation Screening Scale) er nýrri af nálinni og hentar vel til að meta einkenni óráðs samhliða daglegri umönnun sjúklinga. ${ }^{31,32}$

\section{Efniviður og aðferðir}

Kerfisbundin fræðileg samantekt (systematic literature review) var gerð til að fá ítarlegt yfirlit yfir algengi, áhættupætti og afleiðingar óráðs eftir hjartaaðgerð. Við pessa kerfisbundnu fræðilegu samantekt var leitað rannsókna í premur gagnagrunnum: Web of Science, Cinahl og PubMed. Til að ná yfir flestar af peim rannsóknargreinum sem birtar voru á tímabilinu var hugað að pví að gagnagrunnarnir innihéldu greinar vandaðra tímarita en væru ólíkir innbyrðis. Leitarorðin voru: delirium, surgery, postoperative, risk factor, outcome, prevention og cardiac surgery. Við gagnaöflun voru sett eftirfarandi skilyrði: að rannsóknargrein væri birt á árunum 2005-2013, væri á ensku, að í úrtaki væru einungis fullorðnir hjartaskurðsjúklingar (18 ára eða eldri), að í úrtaki væru að lágmarki 50 pátttakendur, að greint væri á skýran hátt frá pví hvernig greining á óráði hafi farið fram og að greiningin byggði á DSM-IV eða öðrum viðurkenndum greiningarviðmiðum og að greining óráðs færi fram á sjúklingum á legudeild, annaðhvort með beinu klínísku mati eða út frá einkennum skráðum í sjúkraskrá. Sett var krafa um að notuð væru greiningarviðmið DSM-IV til greiningar út frá skráðum einkennum í sjúkraskrá. Hér voru útilokaðar rannsóknir sem greindu ekki frá pví hvernig óráð var metið og rannsóknir par sem óráð var ekki greint með stöðluðu matstæki eða út frá viðurkenndum greiningarviðmiðum. Pessar kröfur auka líkur á pví að niðurstöður rannsóknanna gefi rétta mynd af vandamálinu. Ákveðið var að útiloka rannsóknir með úrtökum sjúklinga á gjörgæsludeild par sem margir pættir á gjörgæslu eru frábrugðnir pví sem gerist á legudeild og hóparnir pví ekki sambærilegir. Einnig pótti pað gefa ranga mynd af algengi óráðs að taka með niðurstöður par sem eingöngu var verið að meta einkenni á gjörgæsludeild í ljósi pess að hjartaskurðsjúklingar dvelja par að jafnaði í einn til tvo sólarhringa eftir aðgerð, en einkenni óráðs koma jafnan fram á 2.-4. degi eftir slíkar aðgerðir. Ekki er útilokað að rannsóknir sem ekki hafa verið birtar í peim gagnagrunnum sem leitað var í skipti máli.

\section{Niðurstöður}

Algengi óráðs í kjölfar opinnar hjartaaðgerðar

Pað fundust 27 rannsóknargreinar sem birtu tölur um algengi óráðs í kjölfar opinnar hjartaaðgerðar og var algengið á bilinu 3-87\% (tafla II). Pessi breytileiki skýrist meðal annars af ólíkum greiningaraðferðum og pá helst hvenær og hve oft óráðið var metið, af aldurskiptingu pátttakenda í rannsóknunum og af mati á vitrænni getu fyrir aðgerð. Oftast voru notuð greiningarviðmið DSM-IV $33,36-41$ eða stöðluð matstæki. ${ }^{31,42-57}$ Algengi óráðs var lægst pegar greiningin byggði á öðrum greiningarviðmiðum og par sem ekki fór fram reglubundin skimun eða mat á óráðseinkennum með stöðluðum matstækjum. ${ }^{58,59}$ Annar páttur sem skýrir breytileikann er að úrtök rannsóknanna voru ólík varðandi aldur pátttakenda og pátttöku einstaklinga með pekkta heilabilun eða óráð fyrir skurðaðgerð. Tvær rannsóknir settu fram aldursskiptar niðurstöður á algengi. Í annarri voru pátttakendur 18 ára og eldri og mældist óráð hjá páttakendum yngri en 70 ára 10,5\%, hjá 70-74 ára $25,4 \%$, hjá $75-79$ ára $32,4 \%$ og 40,7\% hjá peim sem voru 80 ára eða eldri. ${ }^{48}$ Hin rannsóknin sýndi að 4,3\% peirra sem voru undir 60 ára fengu óráð en $24,7 \%$ peirra sem voru 60 ára eða eldri. ${ }^{60}$ Sjö rannsóknir útilokuðu einstaklinga með vitræna skerðingu fyrir aðgerð. Í peim rannsóknum var algengi óráðs á bilinu 11,54\% ${ }^{36}$ til 34\%. ${ }^{37}$

\section{Áhættupættir óráðs eftir opna hjartaaðgerð}

Pað voru 23 rannsóknir sem greindu frá útsetjandi áhættupáttum og 17 frá útleysandi áhættupáttum í tengslum við opnar hjartaaðgerðir (töflur III og IV). Í dálki yfir óháða áhættupætti er búið að útiloka áhrif annarra breyta með margpátta aðhvarfsgreiningu. Í aftasta dálki sést fylgnistuðull (OR/RR) og p-gildi óháðra áhættupátta, eða áhættupátta par sem ekki var gerð aðhvarfsgreining.

\section{Útsetjandi áhættupættir óráðs}

Yfirlit rannsóknanna á útsetjandi áhættupáttum má sjá í töflu III. Niðurstöður 12 rannsóknanna sýndu fram á marktæk tengsl hærri aldurs og óráðs. ${ }^{35-38,46-48,51-53,58,60}$ Lakari niðurstöður á MMSEprófi (Mini Mental State Examination) fyrir aðgerð hafði marktæk tengsl við óráð eftir aðgerð í 8 af peim 15 rannsóknum sem skoðuðu tengsl óráðs og frammistöðu á prófinu. ${ }^{36,39,50-53,57,60}$ MMSE-prófið er algengasta skimunarprófið fyrir vitræna getu og gefur stig 
frá 0-30. Pá fundust í einni rannsókn tengsl milli gleymsku fyrir og óráðs eftir hjartaaðgerð. ${ }^{57}$ Sjúklingar með alvarlegt punglyndi fyrir aðgerð voru útsettari fyrir óráði en peir sem ekki glíma við slíkt. ${ }^{36,39,52,54,60}$ Saga um heilablóðfall og skammvinnt blóðrek til heila tengdust aukinni hættu á óráði, sem og sjúkdómar í hálsslagæðum (carotis arterial disease). ${ }^{40,52,56,58}$ Aðrir áhættupættir óráðs sem komu fram í fyrrgreindum rannsóknum voru: að vera karlkyns, ${ }^{50}$ gáttaflökt fyrir aðgerð, ${ }^{36,60}$ blóðleysi, ${ }^{39,54,60}$ verkir fyrir aðgerð, ${ }^{41,55}$ hækkað kreatíníngildi í blóði, ${ }^{42,56}$ langvarandi hjartabilun, ${ }^{58}$ sykursýki, ${ }^{41,47}$ skert geta til að sinna almennum athöfnum daglegs lífs (instrumental activities of daily living) ${ }^{51}$ og lægri líkamspyngdarstuðull. ${ }^{52}$

\section{Útleysandi áhættupættir óráðs}

Samantekt 17 rannsókna sýna hvaða pættir tengdir skurðaðgerð og svæfingu skipta máli varðandi hættu á óráði (tafla IV). Peir sem fara í aðgerð á hjartalokum eða loku- og kransæðahjáveituaðgerð eru í aukinni hættu á óráði umfram pá sem fara eingöngu í kransæðahjáveituaðgerð. ${ }^{6,35,41,57}$ Lengd skurðaðgerðar og svæfingar hefur áhrif, pví lengri tími, pví meiri er hættan á óráđi. ${ }^{47,52}$ Tími á hjartaog lungnavél og tangartími hefur einnig nokkuð að segja varðandi áhættuna. ${ }^{39,42,52,54,57}$ Tími sem viðkomandi er barkapræddur og í pörf fyrir öndunarvél hefur fylgni við óráð. $41,43,60,61$

Nokkrir helstu áhættupættir óráðs sem upp koma eftir aðgerð tengjast súrefnisflutningi í líkamanum, svo sem lágur súrefnisprýstingur og öndunarbilun, ${ }^{49,61}$ lungnabólga, lágt útfall hjarta, ${ }^{58}$ gáttaflökt ${ }^{57}$ og pörf fyrir blóðgjöf. ${ }^{54,57}$ Hækkun á bólgupróteininu CRP í blóði og staðfestar sýkingar hafa einnig fylgni við óráð eftir opna hjartaaðgerð..$^{51,57,58}$

\section{Afleiðingar óráðs eftir opna hjartaaðgerð}

Greint var frá afleiðingum óráðs eftir hjartaaðgerð, svo sem lengri gjörgæsludvöl, lengri sjúkrahúsdvöl, síður útskrift beint heim af sjúkrahúsi, minni færni við daglegar athafnir, lakari lífsgæði eftir aðgerð og hærri dánartíðni í 14 rannsóknargreinum (tafla V). Í töflu V er greint frá niðurstöðum sem reyndust tölfræðilega marktækar og pá miðað við p-gildi undir 0,05.

Af pessum 14 rannsóknum sýndu 8 fram á lengri gjörgæsludvöl hjá peim sem fengu óráð. ${ }^{35,37,42,50,54,58,60}$ Peir hjartaskurðsjúklingar sem fengu óráð lágu marktækt lengur á sjúkrahúsi (10-18 dagar) en peir sem ekki fengu óráð (7-15 dagar). ${ }^{36,37,42,43,47,49,57,58,60}$ Algengara var að peir sem fengu óráð útskrifuðust á annað sjúkrahús, öldrunarstofnun eða endurhæfingardeild, en peir sem ekki fengu óráð. ${ }^{43,54}$ Rudolph og félagar ${ }^{51}$ skoðuðu hvort óráð í kjölfar hjartaaðgerðar hefði áhrif á getu til að sinna almennum daglegum athöfnum. Metin var geta til að sinna verkum eins og að ferðast milli staða, sjá um innkaup, taka inn lyf sem viðkomandi notar að staðaldri og fleira, bæði fyrir aðgerð og svo mánuði og 12 mánuðum eftir aðgerð. Niðurstöður sýndu fram á marktækt meiri hættu á skertri getu til að sinna pessum athöfnum mánuði eftir aðgerð hjá peim sem fengu órád. Að ári liðnu var ekki lengur um marktækan mun að ræða, pó niðurstöðurnar hölluðu í pá áttina.

Langtímarannsókn var gerð á áhrifum óráðs eftir hjartaaðgerð á heilsutengd lífsgæði 6, 18 og 36 mánuðum eftir aðgerð. Niðurstöður sýndu að peir sem ekki fengu óráð eftir aðgerð fundu frekar fyrir bættum heilsutengdum lífsgæðum 6 og 18 mánuðum eftir aðgerð, frá pví sem var fyrir aðgerð. Hjá peim sem fengu óráð eftir aðgerð jukust heilsutengd lífsgæði minna. ${ }^{57}$ Niðurstöður rannsóknar Loponen og félaga sýndu einnig að mun hærra hlutfall peirra sem ekki fengu óráð eftir aðgerð voru á lífi premur árum eftir aðgerðina, eða 96,1\% á móti 77,8\% peirra sem höfðu fengið óráð. Fimm aðrar rannsóknir sýndu einnig fram á marktækt hærri dánartíðni meðal peirra sem fengu óráð samanborið við pá sem ekki fengu órád. $33,42,46,54,58$

\section{Umræða}

Algengi óráðs var mjög mismunandi milli rannsókna, eða á bilinu 3-87\%. Pessi munur skýrist líklega af breytileika úrtaka og greiningarviðmiða. Í rannsóknum sem hér voru skoðaðar fór fram beint klínískt mat á óráđseinkennum sem ýmist var framkvæmt af læknum eða hjúkrunarfræðingum. Раð ætti að tryggja réttmætari niðurstöður en pegar óráð er metið út frá skráningu upplýsinga um einkenni í sjúkraskrá. Rannsóknir sem byggja greiningu óráðs á viðurkenndum greiningarviðmiðum og beinu klínísku mati sem framkvæmt er að minnsta kosti daglega og yfir nokkurra daga tímabil eru líklega pær sem gefa okkur réttasta mynd af raunverulegu umfangi vandamálsins. Í pessari samantekt komu enda fram mun lægri algengistölur í peim rannsóknum par sem ekki fór fram reglulegt endurtekið mat óráðseinkenna. ${ }^{58,59}$ Áhugavert er að sjá niðurstöður rannsókna með ólík úrtök og sjá með pví móti áhrif mismunandi breyta, svo sem vitrænnar skerðingar og aldurs. раð kom glögglega fram að algengi óráðs er hærra í peim rannsóknum sem ekki útilokuðu einstaklinga með vitræna skerðingu. Fjölmargir einstaklingsbundnir og meðferðartengdir pættir geta aukið hættu á óráði eftir opna hjartaaðgerð. Meðal áhættupátta sem voru til staðar fyrir aðgerð voru hár aldur, vitræn skerðing, æðasjúkdómar og gáttatif. Saga um heilablóðfall eða skammvinna blóðpurrð í heila var einnig meðal áhættupátta. Punglyndi reyndist vera stór áhættupáttur óráðs og peir sem glímdu við alvarlegt punglyndi fyrir aðgerð reyndust vera í allt að sexfaldri hættu á óráði samanborið við pá sem ekki glímdu við punglyndi, óháð öðrum áhættupáttum. ${ }^{36}$ Mögulegt er að í peim rannsóknum par sem punglyndiseinkenni greindust fyrir aðgerð, hafi vanvirknieinkenni óráðs ranglega verið metin sem punglyndiseinkenni og hluti sjúklinganna pví verið með ógreint óráð fyrir aðgerð. peirri spurningu hefur verið velt upp, hvort gleymska fyrir aðgerð geti stafað að einhverju leyti af undirliggjandi punglyndi, en rannsóknarniðurstöður hafa sýnt fram á að peir sem finna fyrir gleymsku fyrir aðgerð reynast í marktækt meiri hættu á óráði en peir sem ekki fundu fyrir slíku. ${ }^{57}$

Ýmsir pættir tengdir skurðaðgerð og svæfingu reyndust óháðir áhættupættir óráðs. Nokkrir af helstu áhættupáttum óráðs sem upp koma eftir aðgerð tengjast súrefnisflutningi í líkamanum, svo sem gáttatif, lágt útfall hjarta og lágur súrefnisprýstingur í blóði. Notkun morfínskyldra lyfja í verkjameðferð tengdist auknum líkum á óráði hjá skurðsjúklingum. ${ }^{61}$ Aðrar rannsóknir hafa hins vegar sýnt að verkir og notkun mjög lítilla skammta ópíóía auki líkur á óráði. ${ }^{41,56,62}$ Engin peirra rannsókna sem hér voru til skoðunar sýndu hins vegar fram á að verkir eftir aðgerð væru beinn áhættupáttur óráðs, en ein rannsókn sýndi fram á tengsl verkja fyrir aðgerð og óráðs eftir aðgerð. ${ }^{41}$ Með tilliti til rannsókna á öðr- 
um skurðsjúklingum sem sýna fram á tengsl verkja og óráðs eftir aðgerð er ekki ólíklegt að verkir hafi sambærileg áhrif á hjartaskurðsjúklinga. Afturskyggn lýsandi rannsókn á 100 inniliggjandi sjúklingum með óráð leiddi í ljós að hjá peim sem voru útsettir fyrir óráði við innlögn voru ómeðhöndlaðir verkir líklegri til að ýta undir óráð heldur en aðrir áhættupættir. ${ }^{8}$ Varhugavert er pví að forðast með öllu sterk verkjalyf fyrir einstaklinga í óráði eða í hættu á óráði, heldur er beinlínis mikilvægt að veitt sé áhrifarík verkjameðferð.

Óráð eftir opna hjartaaðgerð getur haft ýmsar afleiðingar í för með sér, svo sem hærri dánartíðni, lengri gjörgæsludvöl, lengri sjúkrahúsdvöl og auknar líkur á útskrift á annað sjúkrahús, öldrunarstofnun eða endurhæfingardeild. Geta til að sinna daglegum athöfnum reyndist frekar skert hjá peim sem fengu óráð. Aukin tíðni fylgikvilla á borð við sýkingar voru jafnframt algengari meðal peirra sem fengu óráð. Aðrar rannsóknir á hjartaskurðsjúklingum hafa einnig sýnt fram á aukna sýkingarhættu hjá peim sem fá óráð eftir hjartaaðgerð, meðal annars sýkingu í bringuskurði og aukna hættu á sýklasótt. ${ }^{57,63,64}$

Forvarnir gegn óráði beinast að pví að draga úr pekktum áhættupáttum, en marga peirra er hægt að hafa áhrif á, svo sem að koma almennu líkamlegu ástandi í betra horf. Á pann hátt má fækka óráðstilfellum, draga úr einkennum og stytta tímann sem ástandið varir. Ráðgjöf öldrunar- eða óráðsteymis myndi jafnframt falla undir forvarnir ${ }^{65}$ en óráðsteymi hafa gagnast vel par sem pau hafa verið starfrækt og reynst góð til að draga úr kostnaði og stytta legutíma. ${ }^{12}$

Mikilvægt er að greina pá sem eru í aukinni hættu á að fá óráð eftir skurðaðgerð og gagnlegt væri að hafa einhvers konar áhættumat í höndum, sambærilegt við pað sem hefur verið próað til að meta hættu á óráði hjá hjartaskurðsjúklingum. ${ }^{52,60}$ Slíkt áhættumat hefur einnig verið próað fyrir aðra hópa skurðsjúklinga, svo sem pá sem fara í mjaðmaaðgerð. ${ }^{19}$ Hollendingar hafa rannsakað áhættupætti óráđs hjá hjartaskurðsjúklingum í yfir áratug og hafa greint fjölda áhættupátta hjá pessum sjúklingahópi. ${ }^{34}$ Pá pekkingu má nota til að hanna gátlista sem metur hættu á óráði. Með pví að greina pá sem eru í áhættu væri hægt að hafa sérstakar gætur á peim hópi og veita markvissa fyrirbyggjandi meðferð. Parna gætu komið inn pættir eins og að skima markvisst fyrir vitrænni skerðingu hjá sjúklingum sem leggjast inn til aðgerða. Рað hefur sýnt sig að reglubundin skimun fyrir óráðseinkennum hjá sjúklingum í áhættuhóp eykur líkur á pví að vandamálið greinist snemma og flýtir par af leiðandi fyrir viðeigandi íhlutun en forvörn er einkum mikilvæg fyrir pað að lyfjameðferð við óráði sem pegar er fram komið er ekki árangursrík. ${ }^{16}$

Nokkrar meðferðir hafa verið próaðar með pað markmið að draga úr óráðstilfellum. Meðal peirra er HELP-forvarnarmeðferðin (Hospital elder life program) ${ }^{66}$ en sýnt hefur verið fram á góðan árangur af henni. HELP miðar meðal annars að hreyfingu fljótt eftir aðgerð, eflingu hugarstarfs og góðri næringu ${ }^{66}$ HELP hefur verið prófuð á litlu úrtaki hjartaskurðsjúklinga $(n=32)$ par sem niðurstöður sýndu fram á fækkun áhættupátta óráðs hjá peim sem fengu pá meðferð. ${ }^{67}$ Aðrar sambærilegar forvarnarmeðferðir hafa verið próaðar og prófaðar ${ }^{65}$ meðal annars ráðgjöf frá öldrunarhjúkrunarfræðingi og öldrunarlækni par sem áhersla var meðal annars á að efla hugarstarf, bæta skynjun, auka áttun og hreyfingu, veita eftirlit með vökva- og næringarinntekt og aðstoða við að leysa verkja- og svefnvandamál. Nýverið voru gefnar út Klínískar leiðbeiningar um greiningu, forvarnir og meðferð við óráði á Landspítala $^{32}$ en pær byggja á leiðbeiningum NICE (National Institute of Clinical Excellence). Par er áhersla lögð á að greina áhættupætti fyrir óráði innan sólarhrings frá innlögn, skima eftir einkennum óráðs hjá peim sem teljast í áhættuhóp og veita peim fjölpætta fyrirbyggjandi meðferð. ${ }^{32}$

\section{Samantekt}

Óráð er algengt en jafnframt alvarlegt vandamál sem getur komið upp eftir opnar hjartaaðgerðir. Meðal áhættupátta eru hár aldur, vitræn skerðing, bráđaaðgerð, lágt útfall hjarta, lengri tími á hjartaog lungnavél, gáttatif og sýkingar. Afleiðingar óráðs eru fjölmargar og geta verið varanlegar. Óráð er hægt að fyrirbyggja að einhverju leyti með pví að sporna við pekktum áhættupáttum. Рað er pví mikilvægt að pekkja pá og greina snemma svo hægt sé að veita fyrirbyggjandi meðferð. 


\section{Heimildir}

1. Diagnostic and statistical manual of mental disorders DSM-IV (4. útgáfa). American Psychiatric Association Washington DC 2000.

2. Saczynski JS, Marcantonio ER, Quach L, Fong TG, Gross A, Inouye SK, et al. Cognitive Trajectories after Postoperative Delirium. N Engl J Med 2012; 367: 30-9.

3. Schuurmans MJ, Duursma SA, Shortridge-Baggett LM. Early recognition of delirium: review of the literature. J Clin Nurs 2001; 10: 721-9.

4. Koebrugge B, Koek HL, Wensen R, Dautzenberg $\mathrm{P}$, Bosscha K. Delirium after abdominal surgery at a surgical ward with a high standard of delirium care: Incidence, risk factors and outcomes. Digestive Surg 2009; 26: 63-8.

5. Tropea J, Slee J, Brand CA, Gray L, Snell T. Clinical practice guidelines for the management of delirium in older people in Australia. Aust J Age 2008; 27: 50-156.

6. Koster S, Hensens AG, Schuurmans MI, van der Palen, Risk factors of delirium after cardiac surgery. A systematic review. Eur J Cardiovasc Nurs 2010; 10: 197-204.

7. Inouye SK, Foreman MD, Mion LC, Katz KH, Cooney LM. Nurses' recognition of delirium and its symptoms. Comparison of nurse and researchers ratings. Arch Intern Med 2001; 161: 2467-73

8. Robinson S, Vollmer C, Jirka H, Rich C, Midiri C, Bisby D. Aging and delirium: Too much or too little pain medication? Pain Manage Nurs 2009; 9: 66-72.

9. Milisen K, Foreman MD, Wouters B, Driesen R, Godderis J, Abraham IL, Broos PL. Documentation of delirium in elderly patients with hip fracture. J Geronto Nurs 2002; 28: 23-9.

10. Flagg B, Cox L, McDowell S, Mwose JM, Buelow JM Nursing identification of delirium. CNS 2010; 24: 260-6.

11. British Geriatrics Society and Royal College of Physicians. The for the prevention, diagnosis and management of delirium in older people. National guidelines 2006.

12. Michaud L, Büla C, Berney A, Camus V, Voellinger R Stiefel F, et al. Delirium: Guidelines for general hospitals. J Psychosom Res 2007; 62: 371-83.

13. Delirium: diagnosis, prevention and management. National institute for health and clinical excellence, London 2010.

14. Marcantonio ER, Flacker JM, Wright RJ, Resnick NM Reducing delirium after hip fracture: a randomized trial. J Am Geriatr Soc 2001; 49: 516-22.

15. Milisen K, Lemiengre J, Braes T, Foreman MD. Multicomponent intervention strategies for managing delirium in hospitalized older people: systematic review. J Adv Nur 2005; 52: 79-90.

16. Inouye SK, Westendorp RGJ, Saczynski J.S. Delirium in elderly people. Lancet 2014; 383: 911-22.

17. Fjármálasvið Landspítala. Upplýsingar frá fjármálasviði hag- og upplýsingamál. 2014. Óútgefin gögn.

18. Afonso A, Scurlock C, Reich D, Raikhelkar J, Hossain S, Bodian C, et al. Predictive Model for Postoperative Delirium in Cardiac Surgical Patients. Sem Cardiothorac Vasc Anesth 2010; 14: 212-7.

19. Kalisvaart KJ, Vreeswijk R, Jonghe JF, Ploeg T, van Goo WA, Eikelenboom P. Risk factors and prediciton of postoperative delirium in elderly hip-surgery patients: Implementation and validation of a medical risk factor model. J Am Geriatr Soc 2006; 54: 817-22.

20. Landlæknisembættið (e.d.). Stöðluð kóðun í albjóðlegum flokkunarkerfum Landlæknisembættisins. skafl.is/ - september 2011.

21. Maldonado JR. Pathoetiological model of delirium: comprehensive understanding of the neurobiology of delirium and an evidence-based approach to prevention and treatment. Crit Care 2008: 24: 789-856.

22. Steiner LA. Postoperative delirium. Part 1: pathophysiology and risk factors. Eur J Anaesth 2011; 28: 628-36.

23. Maclullich AM, Anand A, Davis DH, Jackson T, Barugh AJ, Hall RJ, et al. New horizons in the pathogenesis, assessment and management of delirium. Age Ageing 2013; 42: 667-74

24. Bokeriia LA, Golukhova EZ, Polunina AG. Postoperative delirium in cardiac operations: microembolic load is an important factor. Ann Thorac Surg 2009; 88: 349-50; author reply 350-1.

25. Gemert van LA, Schuurmans MJ. The NEECHAM confusion scale and the delirium observation screening scale: Capacity to discriminate and ease of use in clinical practice. BMC Nursing 2007; 6: 3 .

26. Tune LE, Egeli S. Acetylcholine and delirium. Dement Geriatr Cogn Disord 1999; 10: 342-4.
27. Rudolph JL, Babikian VL, Tranor P, Pochay VE, Wigginton $\mathrm{JB}$, Crittenden $\mathrm{MD}$, et al Microemboli are not associated with delirium after coronary artery bypass graft surgery. Perfusion 2009; 24: 409-15.

28. Inouye SK. Predisposing and precipitating factors for delirium in hospitalized older patients. Dem Geriatric Cogn Dis 1999; 10: 393-400.

29. Registered Nurses Association of Ontario. Nursing best practice guideline. Shaping the future of nursing. Screening for delirium, dementia and depression in older adults. Registered Nurses Association of Ontario 2003. rnao.org/bestpractices/PDF/BPG DDD.pdf - apríl 2010.

30. Radtke FM, Franchk M, MacGuill M, Seeling M, Lütz A, Westhoff $S$, et al. Duration of fluid fasting and choice of analgesic are modifiable factors for early postoperative delirium. ESA 2010; 27: 411-6.

31. Schuurmans MJ, Shortrigde-Baggett LM, Duursma SA. The delirium observation screening scale: A screening instrument for delirium. Res Theor Nurs Pract: Intern J 2003; 17: 31-50.

32. Klínískar leiðbeiningar um greiningu, forvarnir og meðferð við óráđi. Landspítali, Reykjavík 2015.

33. Koster S, Hensens AG, Oosterveld FG, Wijma A, van der Palen J. The delirium observation screening scale recognizes delirium early after cardiac surgery. Eur J Cardiovasc Nurs 2009; 8: 309-14.

34. Koster S, Oosterveld FG, Hensens AG, Wijma A, van der Palen J. Delirium after cardiac surgery and predictive validity of a risk checklist. Ann Thorac Surg 2008: 86: 1883-7.

35. Palmbergen WA, Sonderen A, Keyhan-Falsafi AM, Keunen RW, Wolterbeek R. Improved perioperative neurological monitoring of coronary artery bypass graft patients reduces the incidence of postoperative delirium: the Haga Brain Care Strategy. Interact Cardiovasc Thorac Surg 2012; 15: 671-7.

36. Banach M, Kazmierski J, Kowman M, Okonski P, Sobow $\mathrm{T}$, Kloszewska I, et al. Atrial fibrillation as a nonpsychiatric predictor of delirium after cardiac surgery: A pilot study. Med Sci Monit 2008; 14: CR286-91.

37. Maldonado JR, Wysong A, van der Starre P, Block T, Mille C, Reitz BA. Dexmedetomidine and the reduction of postoperative delirium after cardiac surgery. Psychosomatics 2009; 50: 206-17.

38. Shioiri A, Kurumaji A, Takeuchi $\mathrm{T}$, Matsuda $\mathrm{H}$, Arai $\mathrm{H}_{\text {, }}$ Nishikawa T. White matter abnormalities as a risk factor for postoperative delirium revealed by diffusion tensor imaging. Am J Geriatr Psych 2010; 18: 743-53.

39. Tully PJ, Baker RA, Winefield HR, Turnbull DA. Depression, anxiety disorders an type $\mathrm{D}$ personality as risk factors for delirium after cardiac surgery. Aust NZ J Psych 2010; 44: 1005-11

40. Otomo S, Maekawa K, Goto T, Baba T, Yoshitake A. Preexisting cerebral infarcts as a risk factor for delirium afte coronary artery bypass graft surgery. Interact Cardiovasc Thorac Surg 2013; 17: 799-804.

41. Smulter N, Lingehall HC, Gustafson Y, Olofsson B, Engstrom KG. Delirium after cardiac surgery: incidence and risk factors. Interact Cardiovasc Thorac Surg 2013, 17: $790-6$

42. Bakker RC, Osse RJ, Tulen JH, Kappetein AP, Bogers AJ. Preoperative and operative predictors of delirium after cardiac surgery in elderly patients. Eur J Cardiothorac Surg 2012; 41: 544-9.

43. Detroyer E, Dobbels F, Verfaillie E, Meyfroidt G, Sergean $\mathrm{P}$, Milisen L. Is preoperative anxiety and depression associated with onset of delirium after cardiac surgery in older patients? A prospective cohort study. J Am Geriatr Soc 2008; 56: 2278-84.

44. Gamberini M, Bolliger D, Buse G, Burkhart CS, Grapow,M, Gagneux A, et al. Rivastigmine for the prevention of postoperative delirium in elderly patients undergoing elective cardiac surgery- A randomized controlled trial. Crit Care Med 2009; 37: 1762-8.

45. Hudetz J, Patterson KM, Iqbal Z, Gandhi SD, Byrne AJ Hudetz AG, et al. Ketamine attenuates delirium after cardiac surgery with cardiopulmonary bypass. JCVA 2009; 23: 651-7.

46. Koster S, Hensens AG, Schuurmans MJ, van der Palen J. Consequences of delirium after cardiac operations. Ann Thorac Surg 2012; 93: 705-11

47. Mu D, Wang D, Li L, Shan G, Li J, Yu Q et al. High serum cortisol level is associated with increased risk of delirium after coronary artery bypass graft surgery: a prospective cohort study. Crit Care 2010; 14: R238-48.

48. Osterbrink J, McDonough JP, Ewers A, Mayer H. The occurrence of acute postoperative confusion in patients after cardiac surgery. Sci World J 2005; 5: 874-83.
49. Prakanrattana U, Prapaitrakool S. Efficacy of risperidone for prevention of postoperative delirium in cardiac surgery. Anaesth Intens Care 2007: 35: 714-9.

50. Rudolph JL, Jones RN, Grande LJ, Milberg WP, King EG, Lipsitz LA, et al. Impaired executive function is associated with delirium after coronary artery bypass graft surgery. J Am Geriatr Soc 2006; 54: 937-41

51. Rudolph JL, Inouye SK, Jones RN, Yang FM, Fong TG, Levkoff SE, et al. Delirium: An independent predictor of functional decline after cardiac surgery. J Am Geriatr Soc 2010; 58: 643-9.

52. Rudolph JL, Jones RN, Levkoff SE, Rockett $\mathrm{C}$, Inouye SK, Sellke FW, et al. Derivation and validation of a preoperative prediction rule for delirium after cardiac surgery. Circulation 2009; 119: 229-36.

53. Saczynski JS, Marcantonio ER, Quach L, Fong TG, Gross A Inouye SK, et al. Cognitive trajectories after postoperative delirium. NEJM 2012; 367: 30-9.

54. Stransky M, Schmidt C, Ganslmeier P, Grossmann E, Haneya A, Moritz S, et al. Hypoactive delirium after cardiac surgery as an independent risk factor for prolonged mechanical ventilation. J Cardiothor Vasc An 2011; 25: 968-74.

55. Tagarakis GI, Tsolaki-Tagaraki F, Tsolaki M, Diegeler A Kazis D, Rouska E, et al. The role of SOAT-1 polymorphisms in cognitive decline and delirium after bypass heart surgery. Clin Res Cardio; 2007: 96: 600-3.

56. Tan MC, Felde A, Kuskowski M, Ward H, Kelly RF, Adabag S, et al. Incidence and predictors of post-cardiotomy delirium. Am J Geriatr Psych 2009; 16: 575-83.

57. Veliz-Reismüller G, Torres HA, van der Linden J, Lindblom D, Jönhagen ME. Pre-operative mild cognitive dysfunction predicts risk for post-operative delirium after elective cardiac surgery. Aging Clin Exp Res 2007; 19: 172-7.

58. Loponen $\mathrm{P}$, Luther M, Wistbacka J, Nissinen J, Sintonen $\mathrm{H}_{,}$ Huhtala $\mathrm{H}$, et al. Postoperative delirium and health related quality of life after coronary artery bypass grafting. Scand Cardiovasc J 2008; 42: 337-44

59. Siepe M, Pfeiffer T, Gieringer A, Zemann S, Benk C, Schlensak C, et al. Increased systemic perfusion pressure during cardiopulmonary bypass is associated withless early postoperative cognitive dysfunction and delirium. Eur J Cardio-Thorac Sur 2011; 40: 200-7

60. Kazmierski J, Kowman M, Banach M, Fendler W, Okonski $\mathrm{P}$, Banys $\mathrm{A}$, et al. Incidence and predictors of delirium after cardiac surgery: Results form the IPDACS study. J Psychiatr Res 2010; 69: 179-85.

61. Burkhart CS, Dell-Kuster S, Gamberini M, Moeckli A Grapow M, Filipovic M, et al. Modifiable and nonmodifiable risk factors for postoperative delirium after cardiac surgery with cardiopulmonary bypass. JVCA 2010; 24 555-9.

62. Morrison RS, Magaziner J, Gilbert M, Koval KJ, McLaughlin MA, Orosz,F, et al. Relationship between pain and opioid analgesics on the development of delirium following hip fracture. J Geronto Series A: Biol Sci Med Sci 2003; 58: 76-81

63. Martin B, Buth KJ, Arora RC, Baskett RJ. Delirium as predictor of sepsis in post-coronary artery bypass grafting patients: a retrospective cohort study. Crit Care 2010; 14: R171.

64. Schimmer C, Reents W, Berneder S, Eigel P, Sezer O, Scheld $\mathrm{H}$, et al. Prevention of sternal dehiscence and infection in high-risk patients: A prospective randomized multicenter trial. Ann Thorac Surg 2008; 86: 1897-904.

65. Kalisvaart $\mathrm{KJ}$, Jonghe JF, Bogaards MJ, Vreeswijk Egberts TCG, Burger BJ, et al. Haloperidol prophylaxi for elderly hip-surgery patients at risk for delirium: A randomized placebo-controlled study. J Am Geriatr Soc 2005; 53: 1658-66

66. Chen CC, Lin M, Tien Y, Yen C, Huang G, Inouye SK. Modified hospital elder life program: Effects on abdominal surgery patients. J Am Surgery 2011; 213: 245-52.

67. Astaneh AN, Khajehmougahi N, Pakseresht S, Ramezan A. The multi component intervention to prevent postoperative delirium after open-heart surgery. Pak J Med Sci 2007; 23: 188. 


\section{ENGLISH SUMMARY}

\section{Delirium after open cardiac surgery:systematic review of prevalence, risk factors and consequences}

Steinunn Arna Porsteinsdóttir ${ }^{1,2}$, Herdís Sveinsdóttir ${ }^{1,2}$, Jón Snædal ${ }^{1,3}$

Delirium is a sudden and usually transient disturbance in consciousness, attention, cognition, perception and emotions. The pathophysiology is unknown but possible causes include neurotransmitter disturbances and inflammation reaction. Delirium is common in patients after open cardiac surgeries and can lead to serious consequences. Research shows that delirium is an underdiagnosed and undertreated problem.

The purpose of this systematic review is to illuminate the prevalence, risk factors and outcome of postoperative delirium following open cardiac surgery. A systematic literature review from 2005-2013 was performed aiming to determine the prevalence, predisposing and precipitating factors and outcome after postoperative delirium following cardiac surgery. Web of Science, PubMed and Cinahl were searched. Findings of the systematic review shows that about one third of patients become delir- ious after cardiac surgery. Primary predisposing factors are advanced age, cognitive impairment, atrial fibrillation, depression and prior history of stroke.

Among precipitating factors are pulmonary bypass, duration of mechanical ventilation, low cardiac output, respiratory failure, pneumonia, infections, blood cell transfusion and post-operative arrhythmias. Delirium causes prolonged hospital stay, reduced activity and higher mortality. Delirium prevention includes reducing risk factors. Delirium is a common and serious complication of open cardiac surgery. Knowledge of risk factors of delirium and regular screening for symptoms of delirium are important to reduce prevalence and to facilitate diagnosis and treatment.

'University of Iceland, Landspitali - The National University Hospital of Iceland, ${ }^{2}$ University of Iceland.

Key words: Delirium, cardiac surgery, prevalence, risk factor, outcome, assessment.

Correspondence: Steinunn Arna Porsteinsdóttir, steitors@landspitali.is 